\title{
NGOs and Environment Protection in Assam
}

\author{
Jhimli Bhattacharjee \\ Assistant Professor, Department of Sociology, Assam University, Silchar
}

\begin{abstract}
Non Governmental Organisations (NGO) are found to play a significant role in environment protection. They are found to be involved in different spheres of environmental activities like protecting biodiversity, reducing environmental pollution and also promoting sustainable livelihood of the people living in close proximity with nature. The present paper shows the role environmental NGOs play in environment protection in Assam, India on the basis of case studies of some major NGOs of Assam.
\end{abstract}

\section{Introduction}

NGOs are occupying a significant place in the different arenas of life. Each sphere of life is now protruded by the NGOs. The role of NGOs or action groups in different sectors is vehemently discussed in different academia along with the realization by the government machineries and the world level organizations like United Nations. The growing challenges to the environment because of the growth oriented development paradigm of the state both in developed and developing countries can be considered as the very cause of the growth of NGOs which have taken up the issue of sustainability and have come up with different actions to combat the problems related to environment safety and sustainability of earth time to time. Though there were organizations which already started to take up the issue of conservation of wildlife even in the last decade of nineteenth century e.g. Sierra Club, which came up in 1892 , the concern for environment and wildlife gradually increased in later years. While the decade of forties and fifties of last century show the appearance of major organizations concerned with environment and wild life, the upsurge of NGOs are seen mainly in seventies and onwards, because of the growing consciousness on environment and threat to nature. This was evident in 1972 Stockholm conference which had drawn a large number of NGOs from the different corners of the world to deal with the issue of development and environment. The 1992 Earth Summit is the landmark for understanding the role of NGOs in environment protection when we find that more than thousand NGOs participated in the summit and took up different initiatives to save the mother earth. Gradually the role of NGOs in environment protection is increasing with the formation of new organizations both at national level and grass root level which not only take the local environmental issues, but also issues which are of global significance.

The increasing importance and role of NGOs in different sectors especially in environment protection makes it necessary to have a knowledge of the grass root level organizations and their activities in environment protection and biodiversity conservation. The present paper thus tries to study the role of NGOs in Assam in India on the basis of the field study of some select NGOs which are primarily involved in environment protection and biodiversity conservation in the state .

\section{Role of Action Groups Revisited}

The role of NGOs is a marked feature for the present era. Small grass root groups and larger urban based NGOs and International organizations have placed environment on the national agenda as well as global agenda. Since the beginning of the 1970s, a number of action groups have raised very crucial issues of environmental policies, like the need for forest conservation, the environmental impact assessment of various multipurpose dam projects and to protect rights of the people affected by the governments or industrial organizations lack of concern for environmental hazards of the undertakings.

Very few studies on the role of NGOs in environmental movements have been done separately. Leilah Landin in her study found that NGOs play a major role in organizing popular movements in Brazil. Landing says that in 1988 Brazil had 447 entities that defined themselves as being at the service of popular groups and movements: 565 entities dealt with the question of blacks ; 196 entities dedicated to women : and 402 entities linked to ecology.

Landin ${ }^{1}$ also says that the groups that are classified as ecological NGOs in Brazil are characterized by high degree of informality and voluntarism and fragmented into minute and localized groups . What they form on is significantly diverse. These are preservation of the environment, defense of flora and fauna, organic

\footnotetext{
${ }^{1}$ Landin, Leila, 1993 “Brazilian Crossroads: People's Groups, Wall and Bridges” in PonnaWignaraja (ed) New Social Movements in the
} South, Sage Publications, New Delhi 
agriculture, appropriate technology, alternative medicines alternative agriculture, esteric knowledge, alternative journalism, struggle against giant dams, defense of indigenous communities, the antinuclear struggle, alternative physical therapies...". Landin thus concludes that they present a huge mosaic of activities, which gain meaning as a whole only because they share common sources of thought and action.

$\mathrm{S}$ Cable and $\mathrm{M}$ Benson ${ }^{2}$ discussed about the community based grassroots environmental organization as a new form of social control against rising environmental justice as he says "Emerging in the 1980s , community based grassroots environmental organizations represent a new trend within the larger environmental movement. He said unlike well known lobbying organizations such as Sierra Club and the Natural resources Defense Council, these Grassroots organizations focus specifically on local environmental problems and are less concerned with National environmental policy. For them these community based grass root organizations are not concerned about changing the law, but more on enforcement of Law.

In the Indian context, Guha ${ }^{3}$ considers the organization of the victims of environmental degradation by action groups as political expressions of Indian environmentalism while other being material and ideological. For him environmental action groups working with such people have embarked upon three distinct and interrelated sets of initiatives. First, through a process of organization and struggle they have tried with varying degrees of success to prevent ecologically destructive economic practices. Second, they have promoted the environmental messages through the skillful use of the media, and more innovatively, via informal means such as walking tours and eco-development camps. Finally, social action groups have taken up programmes of environmental rehabilitation (e.g. afforestation and soil conservation ), restoring degraded village ecosystems thereby enchanting the quality of life of its inhabitants.

Shiva and Bandopadhyaya ${ }^{4}$ focused on the role of youth organization $s$ in expressing opposition against the mining project of Bharat Aluminium Company ( BALCO) in the Gandamardhan hills of Orissa. They also maintained the role of volunteers in Chipko movement to led thousands of villagers in a peaceful resistance to oppose the reckless functioning of lime stone quarries that is seen by the people as a direct threat to their economic and physical survival.

Rumki Basu ${ }^{5}$ focused on the Narmada Bachao Andolan and saw it as one of the most vociferous anti dam groups which opposed the construction of the Rs. 9000 crore multipurpose Project on the Narmada river and thus crystallized it into a movement against large dams. While the actions of the NBA have revolved round resisting the governments erforts to move and relocate people living in the submergence area, particularly in Maharastra and Madhya Pradesh, its ideological position has centered on questioning the direction of development projects which does not weigh the benefits of the costs of projects like the Narmada for the local people in the area. Basu also focused on the role of Tehri BandhVirodhi Samiti, a group of local activists in anti dam campaigning against the Rs. 3465 croreTehri Hydro Electric project in Garhwals in Himalayas. The role of action groups is also discussed by Pravin Seth ${ }^{6}$. He showed how Kerala Sastra Sahitya Parishad , an NGO with an excellent record of creating scient awareness and people oriented development, studied the case of pollution by the units of Gwalior Rayons built by Birlas in Kerela. The study clearly brought out the extent of environmental hazards caused to the down stream villages which created a spirited movement against the factory and forced the factory owners to close down their units. He also showed the tremendous role played the action groups for taking measures against the MNC that caused the disaster in Bhopal.

Mathew Aerthayil ${ }^{7}$ also focused on the role of action groups . Kerala Swatantra Malsya Thozhilali Federation (KSMTF), a state level nonparty political organization of traditional fish workers of Kerela spearheaded the fish workers movement. KSMTF, as maintained by Aerthayil, used both conciliatory ( the factors which are constitutional and are a part of democratic process) and confrontational ( direct action, such as dharna, demonstration, boycott , violence etc ) means to achieve their goal

Kishore Saint ${ }^{8}$ has maintained that voluntary effort has had a key role not only in highlighting the crisis but also in evolving a methodology for a people based approach for protection and restoration of Aravalli as a watershed in Southern Rajasthan. Saint maintained that voluntary organizations perceived that watershed

\footnotetext{
${ }^{2}$ Sherry Cable and Michael Benson,1993 ‘Acting Locally :Environmental Injustice and Emergence of Grass-Roots Environmental Organizations. in Social Problems, Vol.40,No.4 (Nov)

${ }^{3}$ Gadgil and Guha , 1995, Ecology and Equity: The Use and Abuse of Nature Routledge

${ }^{4}$ Shiva and Bandopadhyaya, 1998 'Political Economy of Ecological Movements', EPW, June 11.

${ }^{5}$ Basu, Rumki , 1997 "NGOs and Environment Protection in India” in Bava (ed),Non-Governmental Organisations in Development .

Kanishka Publishers, Distributors, New Delhi

${ }^{6}$ Seth, Pravin , 1997, Environmentalism:: Politics, Ecology and Development.

${ }^{7}$ Mathew Aerthyil,1990,Fishworkers Movements in Kerala. Indian Social Institute, New Delhi.

8 Saint, Kshore 'Voluntary Agency's Role in Environmental Protection with Special Focus on Watershed Regeneration' in Dantawala,1998 Dantwala et al. 1998, Social Change through Voluntary Action, Sage Publications, New Delhi
} 
or catchment areas throughout the country are in deep crisis. Voluntary organizations concern for watershed management mainly derives from their perception of the perilous plight of these regions and the people, adibasis and other rural poor, who live there. These organizations have taken up this concern at the national and regional level through research, publication, lobbying and peoples movement for resistance and reconstruction. Saint also pointed out the role of voluntary groups in mobilizing public opinion against the silent valley river project.

\section{Environmental NGOs in Assam :}

According to the directory of Centre for Environment Education (North East), Assam records 152 NGOs which are involved in environment protection. Out of the total number of NGOs mentioned in the directory, 9 NGOs are solely concerned with environment while the rest (about 143 NGOs) take up environment protection as only one among a range of other activities they are concerned with.

In so far as the emergence of these action groups are concerned, it has been seen that the upsurge took place mainly in the last two decades of the twentieth century with 57 organizations recorded in the 1980s and 47 organizations recorded in the1990s. Although there are some mention of the presence of NGOs in the 1950s, 60s and 70s, the numbers were very small. Only 10 organizations are found to have emerged prior to 1950, while the sixties and seventies recorded a scanty presence of 9 and 19 respectively.

Again according to the Directory of NGOs on environment of World Wide Fund for Nature (WWF), ${ }^{9}$ Assam records 66 NGOs which are engaged in environmental protection, 58 of which are registered societies and 2 registered as trusts. The registration status of seven organizations has not been mentioned.

The organizations are spread over different parts of Assam such as Guwahati, Tinsukia, Dibrugarh, Nowgaon, Lakhimpur etc. Significantly, some of the organizations that are located in Guwahati extended their area of operation beyond Assam and the North East. Of a total 66 NGOs operating in the state, 28 operated in Assam and 15 worked on issues beyond Assam. Around 23 NGOs did not record any geographical area of operation. As far as issues of focus are concerned, it has been seen that around 31 NGOs have mentioned environment as the sole focus of their activity. Organizations focusing on environment along with other issues of intervention such as, education, health, child development, rural development, gender issues, upliftment of poor etc. are 33 in number, while the focus of two organizations are not known.

The WWF directory however is not exhaustive of all NGOs, as many of the organizations popular in their geographical area of operation have not been included in the directory. Some of the missing names from the directory are: Green Heart Nature's Club, Nature's Beckon etc., which shows that there are much more to be explored about NGOs of Assam. Moreover, quite a good number of NGOs included in the directory are not seen to be active for a prolonged period of time and are not able to make their presence felt in the state except in name. Further, according to an office bearer of CEE-NE, though the directory was prepared on the basis of the information provided by the organizations, the viability of their existence and activities could not be guaranteed as the CEE itself discovered that some of the NGOs that filled up the forms supplied to them for information were later found to have failed in making their presence in the map of the active NGOs working in the state. This has led CEE-NE to be reluctant to upgrade the information provided in the directory.

Not withstanding the above drawbacks in compiling the directory of NGOs, the presence of environmental NGOs in large number is indicative of environmental activism in Assam as well as in North East India as a whole. A detailed study of the activities of these organisations may help to understand the way and the extent of activism generated by these organizations. The present chapter hence seeks to focus on the activities of certain purposefully selected NGOs of Assam involved in environment protection and through it intends to gain a sharper insight into environmental activism in Assam. Though it is not possible to give a complete list of NGOs working in Assam, drawing from different sources, such as, CEE and WWF directory, it can be said that around 150 NGOs are in some way or other, involved in activities related to protection of environment. Since it will be difficult to study all the organizations in greater detail within a restricted time, around nine NGOs have been taken up as case study to arrive at a detailed understanding of their activities and the kind of issues they are involved in.

In the following pages we provide a brief account of the organizations covered in the study:

\section{Kaziranga Wildlife Society}

Kaziranga wildlife Society was established in the late sixties of the last century in Assam in golaghat by some of the nature's lover to protect the Kaziranga National Park ( KNP), a protected area of the state which hosts two third of the world's one horned Rhinos. The society came up from a sense of responsibility for protection of Rhinos and the Kaziranga National Park when some officials, working in forest department,

\footnotetext{
${ }^{9}$ Fundamental NGOs in India: Adirectory-2004, Eighth Edition, Indira Gandhi Conservation Monitoring Centre, World Wide Fund for Nature-India, Published by WWF-India's ENVIS Centre 07, Indira Gandhi Conservation Monitoring Centre for Environmental Information System of the Ministry of Environment and forest, Government of India ,January 2005.
} 
soil conservation and tourism department stationed at Kohora in the Golaghat district of Assam found the role of people equally important to conserve wildlife as is the role of the Park Authorities. They found a number of weaknesses in the Park authorities which they realized could be overcome if the people also take an active part to protect the park and its wildlife and biodiversity. The society initially emerged as Rhino Club to promote and preserve the endangered Rhinos of Assam. Later on it was renamed as Wildlife Club when it expanded its interest to promote and preserve wildlife of Kaziranga and that of Assam and North East India in general. Late Padmashree awardee Robin Banerjee, a medical doctor by profession and also a naturalist, was the pioneer of the organization and also its first president.

The major activities of the society composed of stopping wildlife crime, as killing of Rhinos , promoting wildlife tourism, organizing health camp, capacity building of local people for their active involvement in conservation of wildlife in their vicinity. It also trains people in a scientific way to protect the wildlife and environment.

Besides the society also engages in promoting and carrying research activities related to wildlife conservation and KNP in particular. the society has established Mahi -Miri research centre with fund from MP's local area development fund. A herbarium has been set up by KWS at Mahi Research Centre. A reference library has also been set up in the name of the pioneer president of the society Robin Baneerjee, who was a great nature lover.

The society does not restrict its activities only to KNP and to provision of scientific expertise, capacity building or educating people, students and other about the significance of wildlife, but also participated in different conventions on biodiversity conservation and raised voice against government if required so. It was one of the twelve NGOs which came together to appeal to the state government for declaration of Joypur, Upper Dihing and Dirak rainforests of Assam (covering an area of 500 sq. $\mathrm{km}$ ) as wildlife sanctuary. It also joined hands with other nature lovers to protect the wasteland area behind the DTO's office at Guwahati where the government had planned to clear the big trees that housed Adjutant Stork, an endangered species of Assam.

An analysis of activities of KWS shows that the main goal of the organization is preservation and conservation of wildlife. All its activities are centered around this. But the strategy involves diverse means. One of which is joining hands with the park authorities to protect the Rhinos. Secondly, it involves villagers in the process either by giving them an orientation to earn an alternative livelihood or use the resources in a sustainable way. Thirdly, networking with other organizations for a common environmental cause which sometimes involves raising voice against insensitive action of any governmental or private bodies towards environment and sometimes to demand for new legislation or policies for protection of wildlife.

\section{Environ}

Environ emerged as an organization to intervene in the sphere of urban pollution.It was started by a college teacher in 2003. The organization has an advisory board consisting of faculty members of university while the executive committee consists of members from different spectrums of society such as entrepreneurs, teachers, journalists and educated youth with qualification in environmental sciences. It has a support base of general members that comprised mostly bonafide students below 25 years of age. In other words, the organization is primarily based on student membership. Sometimes it co-opts volunteers from colleges, National Yuba Kendra, National Service Scheme etc. to carry out different activities.

Environ claims to be the sole organization which works in the area of solid waste management in urban areas, though it is also concerned with urban pollution in general. The major objectives involves survey of natural resources and utilization of natural resources in a sustainable way. The organization is highly critical of the use of non biodegradable cups e.g. plastic cups in tea stalls, any functions, seminars and conferences. As an alternative, the organization started to distribute earthen cups. Organising awareness camps comes under its regular activities.

Environ recognized that solid waste management is an area that is often neglected but very important to intervene. Hence to tackle the problem, it focuses on resource base of trained personal who can take leadership role in waste management in particular and environmental protection in general. The organization is strongly dependent upon bonafide students to take up different initiatives in this regard.

Though small as an organization and new in the chronology in the development of NGOs in Assam, Environ adds to the numerous efforts made by action groups to shape peoples' behaviour as responsible members of society. The garbage management and solid waste management is yet a serious threat to environment particularly in urban areas. However, both the government and the members of society show a kind of aloofness and reluctance to recognize the problem. The city which has exodus of population is more vulnerable to the threat of such kind of pollution. By bringing this threat to the attention of people, Environ adds another dimension of individual's role in the society, not only to produce and reproduce for his own needs but also to recapitulate for a future state of environment. 


\section{Early Birds}

Early Birds, located in Guwahati is another major organization involved in environmental activism. It was established in the year 1991 and registered in the following year i., e., 1992. Though Early Birds initially emerged as an organization to protect the diverse species of birds of Assam, it has gradually incorporated the preservation and protection of wildlife of Assam in its objective. The organization operates mainly in 13 protected zones out of 25 protected zones of Assam.

The regular activities of the organization include organizing health camps for animals and birds, rescue of wildlife if trapped in certain parts of the jungle or in the human habitation. Though it is basically a welfare organization and is counted as one of the eight welfare organizations of Assam recognized by the Animal Welfare Board of India, it involves itself in different spheres of activities starting from awareness campaign for conservation and preservation of wildlife, raising voice for protecting wildlife etc. by bringing up pamphlets and booklets rich in information related to wildlife and distributing these among people or sometimes by networking with other organizations.

Organising health camps in Protected Areas is a major activity of the organization. Till the time of my field work, it has organized more than 115 health camps in different parts of Assam. Besides looking after the health of wildlife in Protected Areas, it also keeps a watch on the health of domestic animals adjacent to these zones as these animals are feared to cause and spread diseases in protected areas.

Since its inception Early Birds has mobilized people and diverse organizations to come under a common umbrella to protect the birds and wildlife of Assam. Besides organizing program by drawing on fund generated by the members, the organization has availed financial support from different national and international organizations such as WWF-NE, WWF Tiger Cell, Assam Science Society and Rhino Foundation.

It has arranged different health camps, nature camps etc. To sensitise and mobilize people around Pobitora Wildlife Sanctuary towards the protection of wildlife and environment, the organization has formed two eco-clubs in the schools around the sanctuary, one at the higher secondary and the other at the ME school level. The eco- clubs had twelve members in the executive body. The major activities of the eco-club are observation of World Environment Day, Earth Day, Wetland Day, Wildlife Week etc.

\section{Ed-En}

Ed-En came up as a registered body in 2000 under the initiative of few college teachers of the department of Botany of Tinsukia College in upper Assam. The society is basically concerned with environment education as it believes that environment education is very essential for sustained development. But it also takes up diverse issues of environmental concern from time to time eg. plantation and raising voice against environmentally insensitive activities of Governmental and private organization, eco-development programs, documentation of environmental problems etc. The society organises training program for school teachers so that they can involve students to protect trees in their vicinity. For example, on January 4-5, 2001, the society organized a two-day teacher training program at Tinsukia, where 25 teachers from 15 high schools besides environmental NGOs participated. The workshop was held under the guidance of Centre for Environment Education-North East, and was supported by SBI, Tinsukia.

The society had been trying to do documentation of various environmental issues inflicting Tinsukia district of Assam pertaining to tea, oil, and coal and the problem of pollution in urban areas. It had prepared slides on various environmental issues in Tinsukia town and entire district and through visual slides it has tried to create awareness among school children. In the wildlife sector it has documented different birds of Tinsukia. In its reaction to the environmental pollution caused by Digboi Oil Refinery in upper Assam the society submitted a memorandum on $14^{\text {th }}$ November, 2000 to Member Secretary, Central Pollution Control Board, New Delhi and IG (Forest ) MOEF, GOI , expressing concern over the environmental pollution caused by Digboi Oil Refinery. As a result, the C.P.C.B.asked Assam State Pollution Control Board to take up the matter. ASPCB issued a closure notice to the refinery after the reply to the show cause notice was found unsatisfactory. Following representations from the refinery, the Board has taken a bank guarantee of five lakhs from refinery as security and kept the closure notice in abeyance till further order.

The organization also keeps a watch over wildlife crime. In March 2003, Ed-en expressed serious concern over the killing of a deer by army personnel at Kokrajhar on March 10, 2003 and sent memorandum to Mr. Balu, Union Minister, MoEF, Mr. George Fernandes, Union Minister of Defence and Mr.PradyutBordoloi, Minister of State, Environment and Forest.

Ed-En also shows similar trend. Though it focuses on environment education by making and creating knowledge on environment problem through survey and documentation of environmental problems mainly of Tinsukia district and its surrounding area, it considers the task as broad based. It not only creates a knowledge base but also tries to involve people by making them aware about the problems and imparting them skills to 
tackle the problem through training programs, educational camps etc. It realized that mere creation of knowledge base and making people aware of it can not meet the demand of the solution of the problem. To solve the problem, it needs people's active involvement in environment protection. Hence it organises plantation programs and other related activities that could help people to live a healthy and environmentally safe life. The organization also keeps a vigil of the wildlife crime, and raises voice against these.

\section{Nature's Beckon}

The organization came up in the year 1982 as a premiere group to conserve the wildlife of Assam. In its initial stage it organized an all Assam environment awareness campaign known as Brahmaputra Barak Valley Natural Environmental Awareness Campaign which was supported by the Ministry of Environment and Forests, Government of India. In 1991, the organization formally registered under societies Registration Act. The major objectives of the organizations are as follows:

- Preservation of the forest and wildlife through people's participation.

- Afforestation and conservation of the biodiversity of the hotspot areas along with the cultivation of traditional food plants of the forest villages.

- To create the environmental awareness among the people in general.

- To impart environmental education to students and youths for developing trained manpower for conservational works.

- To work for social and environmental justice.

The organization undertakes capacity building program, awareness program for conservation of endangered species, prevention of wildlife crime, scientific studies, baseline survey and documentation, networking, advocacy and dissimination of information related to wildlife and its proection.

The organization has played a major role in the conservation of non human primates in the state of Assam. After the discovery of the golden Langur by the members of Nature's Beckon at Chakrashila Hill Reserve in the year 1982 , the organization took active initiative to save the non-human primates throughout the state. The awareness programs of the organizations in the form of poster campaign, writing articles on primates in leading newspapers and journals, organizing meetings and workshops and advocacy with the policy makers for primates motivated other NGOs of the state to work for the conservation of several species of non human primates of Assam which are 'unique and proud possession' of the state. It has relentlessly and successfully lobbied with concerned bureaucrates, state legislators and ministers to declare Chakrashila Hill Reserve as Wildlife Sanctuary and has been successful to upgrade the status of CWS.

The activism of Nature's Beckon can be observed in different aspects. First, in its success in getting Chakrashila Hill Reserve to be declared as Wildlife Sanctuary. Second, its ability to involve villagers to protect the WLS mainly in keeping vigil of wildlife crime.In the words of Datta, "Once the villagers had a confrontation with a large gang of smugglers. They were successful in driving the smugglers out of the forest area and in seizing a huge quantity of their saws, axes, and other tree felling equipment." ${ }^{10}$ Again on another occasion, the villagers with their bows and arrows, surrounded a gang of poachers inside the forest and seized four guns with ammunition and handed over the weapons to the then deputy Commisioner of Dhubri. Besides the villagers do keep a round the clock vigilance of the forest and help in regeneration of forestry.

\section{Aranyak Nature's Club}

Aranyak Nature' Club is located in Guwahati, Assam. It is a registered society working in the field of biodiversity conservation in North East India since 1989. The activity sector of the organization is Environment and Forestry. The club aims to conserve the biodiversity of North East India for the future generation and stop illegal trade on wildlife comprising floras and faunas of the region. The society though had undertaken different action programs and raised voices and continues to raise voice for wild life conservation and protection, it presently focuses mainly on research projects. According to the general secretary there are lots of people who raise voices for protection and conservation but there are very few with professional expertise to undertake research on environmental conservation which is extremely important to protect wildlife in a culturally diverse region such as North East India.

\footnotetext{
10 Datta Soumyadeep, 1998 'An NGO-Initiated Sanctuary: Chakrashila, India' in Kothari,et al., (eds) Communities and Conservation:
} Natural Resource Management in South and Central Asia, Vedamse Books (P) Ltd, New Delhi 
Aranyak is run by young professionals from diverse fields as lawyers, life scientist etc. dedicated and commited to the cause of conservation. About 34 professionals from different fields mostly from the field of life sciences, environmental sciences are working with Aranyak on various research and conservation projects in different aspects of biodiversity in the region. Aranyak emerged as a major activist NGO in the region and has influenced the policy making procedure in the state through its presence in committees like 'Steering Committee for Formulation of New Assam Forest Policy', Rhino Task Force and State Wildlife Advisory Board of the Government of Assam.

Though the organization emphasizes on research, at the same time it frequently raises its voice at appropriate forum against the government's inaction and other illegal action related to wild life and thus involve in different kinds of activism. The organization had been working closely with the forest department of Nameri Wildlife Sanctuary and asked the Government to declare it as National Park which took place in 1997. They have lodged PIL against deforestation, encroachment etc. The High Court though gave verdict to clear the forest from encroachers, still forest areas are not free from encroachers. ANC had organized a press conference along with five other NGOs to express their concern against the poaching of Rhinos in Kaziranga National Park.

Thus the involvement of ANC can be observed to take place in many ways. First, by identifying the environmental problems in the region through research and documentation. Secondly, it works with forest department by extending its support either by providing information or by facilitating or training the staffs of government departments. Thirdly, by networking with other organizations to arrive at solutions to the problems. It is also involved in finding out the faults and illegal actions committed by any private or government body towards the environment.

\section{Nature's Foster}

Nature's foster is a registered society located at Bongaigaon in lower Assam. Set up in 1995, the thrust of the organization is to ensure the protection of the environment through engagement in environmental research, wildlife conservation, environmental education, tree plantation, development of educational material etc.

The organization primarily confines its operations to the state of Assam with most of its members hailing from Bongaigaon in someway or other linked to Bongaigaon. The source of fund is donation, contribution by members and other national and international bodies which subscribe to the objective of the organization.

The major activities of the organization include forest conservation, wetland conservation, community conservation and empowerment, capacity building, study and research on environment and wildlife.

The organization came up after efforts by like minded people concerned about the environment, mainly forestry of Kakoijana Reserve Forest in Bongaigaon. A chance notice of the presence of the Golden Langur in the area led the members to appeal to the government to declare the Kakoijana Reserve Forest as Wildlife Sanctuary. However, with the attainment of further knowledge they gradually realized that wildlife sanctuary alone can not solve the problem of protecting wildlife as people of the fringe areas are dependent upon forests for their fuelwood and other source of livelihood. Hence they felt that a combined effort involving people who are dependent on this forest is required to protect the environment.

With the above realization the organization shifted its focus from Kakoijana Reserved Forest to the protection of Manas as a whole. By forming alliance with other organizations working in the fringe areas, Nature's Foster formed Manas Biosphere Conservation Forum to protect Manas as a whole. These include:

1) Green Forest Conservation, Kokrajhar which has a volunteer force of more than hundred people and also has memorandum of understanding with the Forest Department.

2) Biodiversity Conservation Society, UltapaniKokrajhar.

3) New Horizon, Koilamoila which has twenty volunteers.

4) Ecotourism and Social Welfare Society, KaklungChirang.

Nature's Foster is working in collaboration with Community Conservation (USA). While the organizations as Biodiversity Conservation Society, New Horizon and Eco-tourism and Social welfare Society are financially supported by CC, Green Forest Conservation is supported by Forest department.The role of Natures Foster is coordination of different organization of the forum.

In 2005, Nature's Foster organized a major festival, 'Manas Biosphere Conservation Festival' in Ultapani, the first of its kind, to bring awareness about Manas Biosphere Reserve which is bigger than Manas National Park as it realized that the protection of fringe area is also equally coming under the aegis of Manas Biosphere Reserve.

In March 2008, the organization formed a group of villages into a federation for the protection of the environment. During the course of my field work, the villagers caught a person cutting trees and handed him over to the forest department, on whom a fine of Rs. 1000 has been imposed. In addition to the engagement in environmental protection the villagers are organized into self help groups for regeneration of alternative source of livelihood. 
Other activities of the organization are: the protection of wetlands mainly in Assam, rescue and rehabilitation of wildlife etc.

Nature's Foster is yet another organization which counts significantly in the environmental activism in the state. Though its objective includes a number of issues, it has so far dealt with the issue of two protected areas: Kakoijana Reserved Forest and Manas Biosphere Reserve, besides engaging in the documentation of status of wetlands in Assam, especially of the Bongaigaon district. Besides the regular activities of plantation, rescue of wildlife, awareness generation, the organization is also engaged in the empowerment of village people of fringe areas by providing them environment education and training for self employment. The orgnisation also make people to take part in protecting forest area which is observed in case of their vigil to wildlife crime, a serious problem of protected area.

\section{Centre for Environment Education, North East (CEE, NE)}

This organization is located in Chenikuthi, Guwahati. The organization is the regional branch of CEE Ahmedabad which was established in 1984 under the aegis of Nehru Foundation for development. It was the same year that MoEF came which was more action and policy oriented. So a need was felt to have an organization that would look after the educational aspect of the environment. The organization promotes the objectives of the MoEF by providing educational training and material. Initially CEE reached out through different volunteers and partners but gradually as it started expanding its activities a need was felt to have a full fledged office in the region.

The main thrust of CEE is education for sustainable development. Its activities comprised three major components: capacity building, field study demonstration, and policy intervention. The organization works through advocacy, dialogue. As part of the National Curriculum Framework (NCF), CEE emphasized the point that environment education can not take place in isolation, rather all learning can take place through habitat.

The main goal of the organization is to protect the environment of India through the creation of awareness and education. The objective can be mentioned as training and sustainable development. The organization is highly professional with trained professionals absorbed in different fields.

To save the tigers of protected areas in North East India, the organization has started a project, Save the Tiger project (STP) with a financial support of Rs.4.5 lakhs, from National Fish and Wildlife Foundation. One component of the project is to develop material on tigers of protected areas which included development of CD ROM and stickers on tigers. The project covered Manas Tiger Reserve, Namdapha Tiger Reserve, Nameri National Park and Pakke Wildlife Sanctuary. The other component is capacity building of different categories of people namely NGOs, teachers, forest staff and local entrepreneurs working on alternative livelihood. One hundred schools had been selected in four different locations having 25 schools in each location. Each of these clusters was led by local NGOs. Inspired by CEE two more NGOs have joined the move.

To promote eco- tourism in the state under the guidance of the Union Ministry of Tourism (MoT), CEE has taken up a project sponsored by UNDP in Sualkochi village famous for the production of silk, for capacity building of the people of the village. The construction of infrastructure, however, remained the responsibility of the District Administration which has so far constructed 3 cottages, 1 Kalakendra (community hall), one cafeteria, a welcome gate and an open theatre the later, (though has yet to be completed).

The communities have been provided training in hospitability and management of the site. They have been imparted special training in tourist guide skill, human resource skill and skill of communication. The project was for two years and was to end in 2008. Besides, different types of activities have been initiated for capacity building which includes formation of SHGs, vocational training, promotion of bamboo and cane crafts, special education on banking etc.

In 2002, the organization has launched a program called National Green Corps funded by MoEF. Thus CEE-NE's main work has been in the field of environment education. It works not only in collaboration with government departments such as, MoEF and MoT, but also with international bodies which is revealed by the funds acquired by the organization. As the organization considers environmental education vital in the process of solving environment problems, it uses a variety of methods such as, capacity building and intervention at policy level.

\section{Conclusion}

The study of environmental action groups shows that in Assam, the concern for environment emerged in nineteen sixties and seventies, which shows a trend similar to the scenario at world level and also which shows that the rise of environmental organizations is a phenomenon mainly in the post 1960 . Moreover it is seen that most of the organisations came up under the leadership of educated middle class people, mainly youth and many having teachers and educated youth from University with degree in environmental sciences or related background. Examples can be given of NGOs which gives environmental education as priority as ANC, Nature's Beckon, Environ, Ed-En etc. 
The fund flow of different organizations shows that, though most of the organizations depend on donations and the fund they generate from their own contribution for their day to day activity, many take up projects sponsored by the Government and by International Non Governmental Organizations (INGO). It has been observed that not all the organizations have equal support base, hence the smaller organizations work with bigger organizations as partners, that way a networking or alliance is established as a means of reaching their goal as is seen in case of Manas Alliance. The sources of fund also shows that there is a commonality of goal of local NGOs that connects the grass root level NGOs of Assam with the national and international organization which makes all these organizations part of the common goal of environment protection.

The study of the select action groups of Assam shows that concern for environment is very much prevalent in the state with different organizations taking up different lines of actions to protect the environment. The study also shows that though the NGOs are established institutions, with formal recognition by government of India vide the compulsory registration under the Societies Registration Act and also financial assistance, yet they exhibit high degree of autonomy in so far as their objective is concerned. As is seen many times these organizations do not hesitate to point out the fault of the government and then raise voice to rectify these faults. Besides by trying to empower people to meet their own ends they not only question the viability of the state but prove them as an important force in society and the state.

Though development of the action groups took place out of a felt need to change the degraded status of environment and form part of the bigger movement at the global level, it is difficult to characterize the activities of these organisations as environmental movement. Very often they develop as an institution, with a structure of bureaucratic organization and loose the spontaneous rigor of movement spirit and are concerned more with routinised projects and action. Since the degradation of environment cannot be upgraded in a day or two and is also a complex process that requires long term goal, it is difficult to assess their success or failure in one or two projects. It can be seen that these action groups developed as sustained body to meet the larger environmental goal and their viability cannot be judged by a study of their activity in few years. While most of these organizations are highly influenced by the ideology of conservation and preservation, they also take up livelihood issues mainly alternative means of livelihood for sustainable development a concept which also go with the very vision of preservation of nature.

Three trends have been observed in so far as their intervention is concerned. First to educate and motivate people for sustainable use of natural resources and to generate environmental balance by plantations, abstaining from destruction of flora and fauna and by protecting the same. Second, to intervene at governmental policy level to take up right decisions and steps to protect the environment, examples can be given of Nature's Beckon, Aranyak Nature Club, Ed-en. These organizations do protest, object and criticize any sort of negligence by the Government officials (forest) to maintain the flora and fauna. Sometimes they mobilize demonstrations against government officials and ministers, campaigning by net or by press release or by assembling in public for protest demonstration e. g., participation in the convention organized by North Eastern Social Research Centre, Guwahati to protest the state water policy, raising voice against encroachment in the forest etc.

The study of these NGOs shows that most of these groups in some way or other are involved in some sort of activism using different means to achieve their goal ranging from moderate means like strikes, intervention at policy level, mobilizing people to protect against environmental degradation and government's inaction to put a check on these. 